\title{
Decriminalisation of Drug Use - The Outlook for Reform in Norway
}

HANS FREDRIK MARTHINUSSEN*

\section{Introduction}

After nearly fifty years of war on drugs, the flow of drugs into western societies seems to continue at full strength. The problems of drug use and abuse are as vivid as ever before. The hard police stance has not had visible success in fighting drugs, neither its total use nor its abuse. Cannabis use is more common in prohibition countries like France than in the Netherlands, where it has been sold legally off the streets in Amsterdam for decades.

This has led countries to evaluate their policies on drugs, but as of now, none of the western countries have yet decided to follow Portugal's decision back in 2001 to decriminalise drug use and possession of smaller quanta of drugs for personal use. Although many countries have moved to a liberal position on cannabis and to treat the most heavily addicted users more humanly with medication and health programs, drugs remain strictly forbidden and an important object of policing.

This article will discuss the current legal status in Norway and the possible legal outcome of a recent statement by a majority in the Parliament's Committee on Health that the problem of drug use should no longer be handled by police, but instead be treated as a health issue. This has led to numerous claims in international media that Norway might 
be on its way to decriminalising drug use. ${ }^{1}$ Although this remark has no legislative effect, and thus does not change the current legal regime, it expresses the view of the parties in government at the moment, and recently a commission was established with a mandate to prepare a reform where 'the responsibility for the society's reaction to use and possession of illegal drugs is transferred from the justice sector to the health sector.' Whether this actually will lead to a complete decriminalisation is not clear, and will be further examined in the text below.

Furthermore, the article will give a description of the legal background for the ongoing Norwegian debate on decriminalisation. It will touch upon the central moral and sociological-empirical arguments, including comparative data for drug use in countries with different drug regulation regimes. Finally, it will touch upon the question of possible legislative outcomes of the upcoming reform.

\section{Current legal regime}

In Norway, it is a criminal offense to use or possess all substances listed in the so called 'narcotics list'. Technically, drugs are regulated in the Medicines Act of $1994,{ }^{3}$ which has its own chapter on narcotics. Section 24 states that it is illegal to use or possess narcotics, unless one has a legal access. A legal access will typically be a prescription from a doctor. To obtain legal access by providing false information is also a crime according to $₫ 24$. According to $₫ 31$, violating $₫ 24$ is sanctioned with fines or imprisonment for up to three months.

Even fairly petty cases of possession for own use may, however, be legally classified as storing narcotics, which is more severely sanctioned under the provision in the Penal

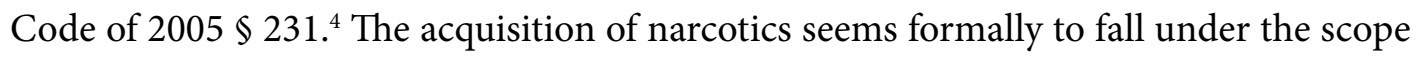

1 See i.a. https://www.independent.co.uk/news/world/europe/norway-drug-law-reformexample-world-initiative-police-bereaved-relatives-warning-a8265311.html, which was even shared by the Norwegian Prime Minister Erna Solberg's facebook page on the $23^{\text {rd }}$ of March. (Last accessed $3^{\text {rd }}$ of May 2018).

2 https://www.regjeringen.no/no/dep/hod/org/styrer-rad-og-utvalg/rusreformutvalget/mandatfor-rusreforutvalget/id2594883/ (last accessed $3^{\text {rd }}$ of May 2018).

3 Act 1992-12-04-132 on medicine, (Lov om legemidler m.v.).

4 Act 2005-05-20-28 on punishment (Penal Code). 
of the Penal Code $\$ 231$, but acquisition of small amounts for personal use is according to practice only treated as possession regulated by the Medicines Act $\$ 24{ }^{5}$

According to official statistics, Norway had 293000 criminal reactions in 2015. The vast majority is traffic violations, accounting for 220000 of these reactions. Almost three fourths of the criminal reactions are so called 'on-the-spot optional fines.' ${ }^{6}$ If we disregard these fines, which do not provide a criminal record and which are used for minor traffic and smuggling violations, Norway had a total of 79500 reactions. Approximately 20000 were (more severe) traffic violations, 15000 crimes for profit, 6000 violent crimes, 12000 breaches of the peace and 22000 drug crimes.

Violations of the provisions on narcotics thus accounted for one fourth of the criminal sanctions in Norway, leading to a criminal record. It must, however, be noted that 4600 cases of driving under the influence of alcohol or drugs are part of the 22000 drug violations. If we disregard traffic violations altogether, including driving under the influence of alcohol or drugs, drug crimes account for approximately $30 \%$ of criminal sanctions.

Breaking down the numbers on drug crimes, approximately 8000 reactions are violations of the provisions in the Medicines Act $₫ 24$. Approximately 4000 violations of the Penal Code $\$ 231$ are sanctioned with fines, which means they are usually minor violations like storing a small amount for personal use. ${ }^{7}$ In other words, there are plenty of ordinary end-users being targeted by police in Norway. Contrary to popular belief and what is often stated by police and politicians, 224 people were given prison sentences in cases where the main offence was violating the provisions on use and petty possession in the Medicines Act. ${ }^{8}$

It is worth noting that these numbers reflect the current state of criminal reactions after drug offenses were no longer counted against the police's clear-up rate goals. In 2013-2014, several Norwegian police districts achieved a remarkable rise in their clearup rates through a large increase in petty drug cases, which lead to a reaction from the public prosecutor ('Riksadvokaten'), eventually leading to these reactions no longer being counted against the goals set for each district's clear-up rate. Harsh corrections were

5 For a more comprehensive treatment of these issues, in particular the finer distinctions between the provisions on use, possession, storing and acquiring drugs, see Jacobsen and Taslaman 2018 pp. 21-25. A general overview of the criminal law on drugs in Norway can be found in Matningsdal, Norsk spesiell strafferett, 2. ed. (Fagbokforlaget 2016) pp. 21-77.

$6 \quad$ 'Forenklet forelegg'.

7 Total petty violations of the narcotics provision in the Penal Code $\$ 231$ amount to approximately 8000 .

8 All statistics are official Norwegian statistics from the Central office for statistics, SSB, available at http://www.ssb.no/straff (last accessed $3^{\text {rd }}$ of May 2018). 2015 is the last year available with full breakdown of the criminal sanctions. 
given to the police for manipulating their clear-up rates by targeting drug addicts. ${ }^{9}$ In the following years, 2015-2016, a clear drop was seen in charges brought for narcotics violations, yet still 34000 total charges were filed for violations of the Medicines Act $\$ 24$ (19 000) and petty violations of the Penal Code $\$ 231$ (15 000). ${ }^{10}$

It must also be pointed out that the Penal Code in $₫ 55$ states that for every fine it must be mandated an alternative prison sentence in case the person in question does not have the means to pay the fine. In practice, this means that many drug addicts end up serving prison sentences without even having appeared in front of a judge.

Of inmates in Norwegian prisons, $60 \%$ have been reported having a drug problem. ${ }^{11}$ In a study published in 2016, half of the inmates in Norwegian prisons reported having used an illegal drug daily in the last six months before serving their sentence. ${ }^{12}$ In 2014 one third of inmates in Norwegian prisons served for drug crimes. ${ }^{13}$

For a complete picture of how Norwegians with drug problems are treated in the criminal system, it must be added that there has been a high degree of controversy on several police policies on fighting drugs. It has been revealed illegal searches of school pupils with dogs, a large number of drug addicts have been expelled from the city centres of the two largest cities in Norway, without proper regard to the legislation on such restraints on the freedom of movement, and the Norwegian ombudsman has criticised the police for leading a stricter practice for suspending driving licences in cases of cannabis use than for alcohol, and without proper regard to the terms set forth for such suspensions in legislation and in practice from the Supreme Court. ${ }^{14}$ All in all, there cannot be much doubt that the combination of the current legislation and how it is carried out by the police, leads to a high degree of stigma around drug use and drug users.

9 See i.a. https://www.aftenposten.no/norge/i/Ok3gO/Riksadvokaten-advarer-politiet-mottallpynting (last accessed $3^{\text {rd }}$ of May 2018).

10 https://www.ssb.no/sosiale-forhold-og-kriminalitet/statistikker/lovbrudda/aar/2017-0306\#content (last accessed $3^{\text {rd }}$ of May 2018).

11 St.meld. nr. 37 (2007-2008) p. 59 (document from the Government to the Parliament).

12 Substance use and health status among Norwegian inmates. Results from the Norwegian Offender Mental Health and Addiction Study (NorMA), SERAF 2016.

13 https://www.ssb.no/sosiale-forhold-og-kriminalitet/statistikker/fengsling/aar/2016-03-16 (last accessed $3^{\text {rd }}$ of May 2018).

14 https://www.sivilombudsmannen.no/wp-content/uploads/2017/06/Politiets-saksbehandling-isaker-om-forerkort-og-kjoreseddel.pdf (last accessed $3^{\text {rd }}$ of May 2018). 


\section{Background for the drive for change}

The Norwegian Parliament and Government are now proposing the first European decriminalisation reform since the Portuguese, which comes as a result of several factors. Most important is probably that Norway has ranked amongst the most lethal drug policy regimes in Europe over the last 15 years, with the most overdose deaths per capita together with Estonia and Sweden, approximately $400 \%$ above EU average. ${ }^{15}$ In a country generally scoring high on living standards, welfare and health, holding a first place on the UN 2016 Human Development Index, ${ }^{16}$ such an abysmal record on drug induced deaths has raised public debate.

Although the number of overdose deaths has been the dominating subject in the public debate concerning a drug policy reform, other arguments have surfaced as well. When preparing the new Norwegian Penal Code of 2005, The Commission on a new Penal Code ('Straffelovkommisjonen') pointed to the harm principle as its overreaching norm for which actions could be criminalised. ${ }^{17}$ This was supported throughout the entire legislative process. ${ }^{18}$

The Commission took a classical starting point in John Stuart Mill's harm principle, by stating that criminal punishment should only be asserted against actions that harm or may harm others. A certain modification in line with much of the current debate on the harm principle follows, where it is stated that this harm principle means that criminal punishment should only be used when there are 'weighty arguments' for doing so, and that such weighty arguments regularly only are present if the action at hand has potential harming effects. ${ }^{19}$ The Commission also dismissed damage to the society's moral as a relevant harm. ${ }^{20}$

A majority in the Commission wanted to decriminalise drug use as a direct consequence of their stance on the harm principle. They stated that criminal sanctions against drug users had clear paternalistic sides, in that drug use only to a very limited degree could inflict harm on others. The main reason for criminalising drug use, to protect the health of the user himself, was not found to be a valid reason for criminalisation. ${ }^{21}$

\footnotetext{
15 http://www.emcdda.europa.eu/data/stats2017/drd_en (last accessed $3^{\text {rd }}$ of May 2018).

16 http://hdr.undp.org/en/2016-report (last accessed $3^{\text {rd }}$ of May 2018).

$17 \quad$ NOU 2002: 4 pp. 79-81. (Preparatory work).

18 See Ot.prp. nr. 90 (2003-2004) chapter 7.5.2 and Innst.O. nr. 72 (2004-2005) chapter 6.2. (Preparatory work).

$19 \quad$ NOU 2002: 4 p. 79.

$20 \quad$ NOU 2002: 4 p. 80.

21 NOU 2002: 4 pp. 80-81 and 330-331.
} 
These arguments did, however, not convince The Norwegian Ministry of Justice. In its final proposal to the Parliament, The Ministry of Justice reached the same conclusion as the minority opinion in the Commission on the new Penal Code: That the use of drugs in an indirect way causes harm to others. It was stated that there are severe effects for next of kin and that decriminalising might legitimate drug use and lead to more use and abuse. In particular, it was pointed to the chilling effect criminal sanctions may have on young people. ${ }^{22}$

In light of growing empirical sociological data, these conclusions draw an increasing amount of criticism. Although several countries have moved on to legalised cannabis trade, only Portugal has completely decriminalised the use and possession of minor quantities of all drugs. Thus, the data on decriminalisation alone is relatively limited. The results from the large Portuguese drug reform are at least clear, with a sharp drop in overdose deaths, a sharp drop in HIV-infections attributed to infections and drug use amongst young adults, which is well below European averages. Portugal also has way below European average of high risk opioid users, and a very low number of drug induced deaths. ${ }^{23}$ Although the reform consisted of much more than simply decriminalisation of drug use and possession, data and drug trends in surrounding countries suggest that there is a direct link between decriminalisation and the reduction Portugal has had in problematic drug use. ${ }^{24}$

Furthermore, the theory that prohibition deters young people from using the illicit drugs lacks support in the recent trends of legalisation in the US. Adolescent use of cannabis has been relatively stable in Colorado and Washington after legalisation in 2014. ${ }^{25}$ A large study of one million American teens between 1991 and 2014 showed that the

NOU 2002: 4 pp. 81 and 331 and Ot.prp. nr. 90 (2003-2004) p. 91. For a more comprehensive outline of the legislative process, see Jacobsen and Taslaman 2018 pp. 30-32.

23 See EMCDDA European Drug Report 2017. (http://www.emcdda.europa.eu/system/files/ publications/4541/TDAT17001ENN.pdf (last accessed $3^{\text {rd }}$ of May 2018)) and EMCDAA Country Drug Report Portugal 2017. (http://www.emcdda.europa.eu/system/files/publications/4508/ TD0116918ENN.pdf).

24 Woods, A decade after drug decriminalization: What can the United States learn from the Portuguese model?, University of the District of Columbia Law Review, vol. 15(1) (2011) pp. 1-31, at 20. See also Huges and Stevens, What can we learn from the Portuguese decriminalization of illicit drugs?, British Journal of Criminology, vol. 50 (2010) pp. 999-1022.

25 See the Substance Abuse and Mental Health Services Administration's report on National Survey on Drug Use and Health, https://www.samhsa.gov/data/sites/default/files/report_2121/ ShortReport-2121.pdf and the Healthy Kids Colorado Survey: https://www.colorado.gov/ pacific/cdphe/hkcs (last accessed $3^{\text {rd }}$ of May 2018). 
legalisation of 'medical marijuana' in 29 US states did not increase teen use. ${ }^{26}$ For more long term trends in young people's use of drugs and the possible effects of criminalisation, it can be pointed out that in the Netherlands, with its famous coffee shops, $16 \%$ of people aged 15-35 used cannabis in the last year according to the European Drug Report 2017. For comparison, one might look to the surrounding countries where cannabis is prohibited: Belgium $10 \%$, Germany $13 \%$, France $22 \%$, Denmark $18 \%$ and United Kingdom $11 \%$. The European average is $14 \% .{ }^{27}$ For Portugal, the number is a mere $5 \%$. As for the youngest in these groups, the ESPAD-report ranks the Netherlands slightly higher. ${ }^{28}$ In the Netherlands, $12 \%$ of 15-16 year olds used cannabis in the last 30 days, which only ranks behind France (17\%), Italy (15\%), Spain (14\%), Czech Republic (13\%) and Bulgaria $(12 \%)$. Other surrounding countries have generally lower use among the youngest group: Belgium $8 \%$, Denmark $5 \%$, while Germany and United Kingdom are not part of the study. In Portugal, the number was $8 \%$. The European average is $8 \%$.

All in all, the Netherlands, with its very liberal stance on cannabis, does not have vastly larger challenges with its youth and their drug use. There are of course a range of factors that affect young people's willingness to try and use cannabis and other drugs. These numbers, i.e. the lack of correlation between the legal status of cannabis and cannabis use, do however strongly suggest that decriminalisation, over even legalisation, does not itself lead to any major increase in problems with drug use and abuse within the younger part of the population. A study by the EMCDDA on the effect of legal reforms on cannabis use in the population also clearly shows the lack of support for the 'signal theory', that prohibition and criminal punishment is a substantial factor in drug use: ${ }^{29}$

26 See Sarvet et al., Medical marijuana laws and adolescent marijuana use in the United States: A systematic review and meta-analysis, Addiction (2018). Doi: 10.1111/add.14136. [Epub ahead of print] (https://onlinelibrary.wiley.com/doi/abs/10.1111/add.14136 (last accessed $3^{\text {rd }}$ of May 2018)), and Hasin, Medical marijuana laws and adolescent marijuana use in the USA from 1991 to 2014: results from annual, repeated cross-sectional surveys, Lancet, vol. 2 no. 7 (2015) pp. 601-608.

27 All data from the EMCDDA European drug reports 2017.

28 See European School Survey Project on Alcohol and Other Drugs, Report 2015: http://www. espad.org/sites/espad.org/files/ESPAD_report_2015.pdf (last accessed $3^{\text {rd }}$ of May 2018).

29 http://www.emcdda.europa.eu/online/annual-report/2011/boxes/p45 (last accessed $3^{\text {rd }}$ of May 2018). 


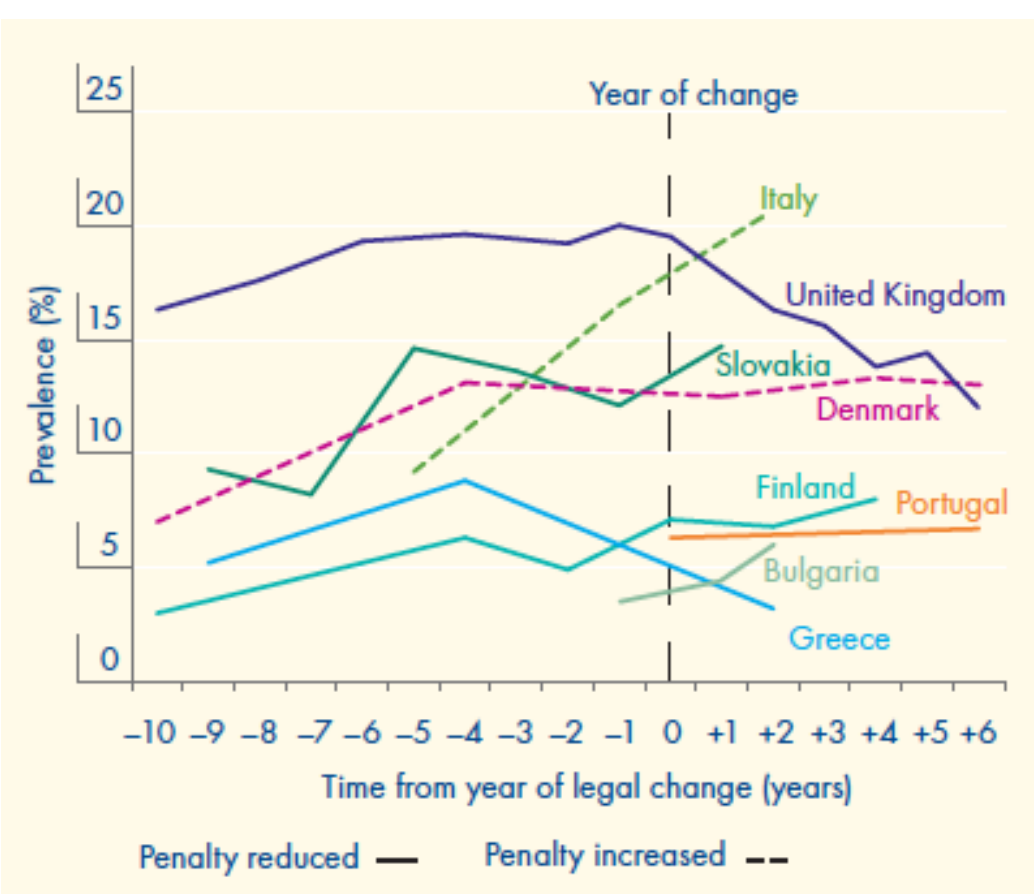

Both the Commission on the new Penal Code and the Ministry of Justice agreed that one side of the harm principle is that the burden of proof for harm should be on the Government when criminalising an action. The burden of proof is considered to be relative: The greater possible harm, the less onerous burden of proof. ${ }^{30}$ Considering the weak foundation for criminalising drug use in the first place, the growing amount of evidence showing that criminalisation is in fact not a significant factor in reducing use and abuse of drugs is an evident source of critique.

When coupled with the fact that other comparable examples of 'indirect harm' are not criminal offenses, the case for upholding the current legal regime on drugs in Norway becomes even weaker. Gambling, for instance, is regularly associated with similar stress on next of kin as drug use. Other typical reactions to childhood abuse like eating disorders or self-harming are treated as health issues, not a criminal offense, in spite of their infliction of stress and unhappiness on relatives and loved ones. ${ }^{31}$

With the very weak evidence for any significant harm preventing effect of criminalising drug use, combined with the lack of comparable other actions being criminalised, the moral issues of criminalisation are even more problematic. If there should be a 'signalling effect' by criminalising drug use, although there is no direct harm from the use

30 NOU 2002: 4 p. 80 and Ot.prp. nr. 90 (2003-2004) p. 92.

31 This argument of harm to oneself or others in this 'indirect way' is thoroughly treated, and predominantly dismissed, by Jacobsen and Taslaman 2018 pp. 36-40 and 42-44. 
itself, those persons using drugs would be punished solely for the protection of others. Their punishment would in other words serve as a warning to deter others from doing the same, even though their action itself was not harmful. The moral of such a sacrifice of some for the protection of others seem highly questionable in itself, and even more so considering which parts of the population are most likely to develop a drug problem.

The outer borders of the harm principle can be hard to define in modern welfare states, and there has been a development in what might be considered a relevant harm. ${ }^{32}$ One might also question the superficial approach to the harm principle as the sole fundamental base for deciding which actions should be criminalised. ${ }^{33}$ There might even be found actual harm in the act of purchasing drugs and thereby supporting the brutal illicit international drug trade. ${ }^{34}$ As shown by Jacobsen and Taslaman, however, finding justification for the Norwegian drug regulation in the harm principle is utterly difficult. ${ }^{35}$

In light of this, I would argue that the current Norwegian drug regime seems to fail basic moral standards for criminal regulation. One might find this conclusion surprising or even rather harsh considering that the Norwegian regulation on drugs is in accordance with international treaties and most other countries' drug laws. There is, however, after 50 years of practicing the current dominating international legal regime, a complete lack of evidence that prohibition is a useful way of limiting drug problems in our society. To the contrary, the evidence that the regulation is harmful is overwhelming. Asking for a more balanced presentation of the empirical data on the effects of criminalisation of drug use, is like asking for a more balanced presentation of the question of global warming. There is quite simply not serious research supported by the academic community showing that criminalisation works, which might be why, among others, OHCHR, WHO, UNAIDS, UNODC, EMCDDA and Human Rights Watch have asked for decriminalisation of drug use and possession as a matter of basic human rights.

On top of these moral issues comes the growing knowledge in the population that alcohol is among the most damaging of all drugs, and in particular when it comes to harm to third parties. The largest studies comparing harms caused by drugs have alcohol on top, also when disregarding the total amount consumed in the population. ${ }^{36}$ In addition, studies are emerging showing a significant drop in alcohol consume in US states that have

32 See in particular Harcourt, The Collapse of the Harm Principle, Journal of Criminal Law and Criminology, vol. 90 (1999-2000) pp. 109-194, with further references.

33 See Jacobsen and Taslaman 2018 pp. 33-34.

34 See Jacobsen and Taslaman 2018 pp. 41-42.

35 Jacobsen and Taslaman 2018 p. 45.

36 Nutt et.al., Drug harms in the UK: a multicriteria decision analysis, The Lancet, vol. 376 no. 9752 (2010) pp. 1558-1565 and van Amsterdam et.al., European rating of drug harms, Journal of Psychopharmacology, vol. 29(6) (2015) pp. 655-660. 
allowed regulated cannabis. ${ }^{37}$ These are scientific advances that seriously questions the classic maxim that 'we have enough problems with alcohol; we do not need more drugs', and emphasises the moral problem of criminalising those using a less harmful drug both for themselves and for the society, than what is legally offered though regulated sales.

On an empirical-sociological level and in a European perspective, one might be tempted to find the Norwegian (or even the Nordic) drug regulation particularly damaging on the most vulnerable parts of the population. Norway, in similarity with the other Nordic countries, is of the countries in Europe with the lowest drug use amongst 15-16-yearolds according to the ESPAD-report. Only $2 \%$ of Norwegian 15-16-year-olds reported cannabis use the last 30 days. Norway is also below the European average in problematic opioid users, but still amongst the countries with the most drug induced deaths. The low teen use of cannabis is consistent with the placement on the Human Development Index: Norwegian teens have less to worry about than many of their European peers, and health care and child welfare services and supervision are at a high level. Still, the problematic use is high and incredibly deadly, not least when seen against the level of welfare and health care. One might perhaps be inclined to conclude that the Norwegian drug regulation sacrifices the part of the population that is not easily deterred by prohibition, those trying to ease their pains of abuse, bad childhoods etc., in order to signal to young people that are not in particular danger of developing an addiction problem, that drugs are not something one should experiment with. At the same time, it is hard to rule out that prohibition itself might be a tempting factor for those youngsters more in danger of addictive drug behaviour. It is often said in Norwegian drug debates by prohibition proponents that the criminal reactions on drug use are in solidarity with those who are vulnerable; those who could handle recreational use should abstain to protect those who cannot. Instead it seems the reality is that those who are not able to abstain and who often will develop an abusive pattern, pay the price for the deterring of the population at large, quite contrary to most of the basic foundations of the Nordic welfare states. Therein lies the strongest drivers for a drug policy reform.

\section{The outlook for a Norwegian drug reform}

The content of the forthcoming Norwegian drug reform is not yet decided. Many issues are under debate, i.e. expansion of the substitution treatment program, possibly including heroin treatment, and allowing all drugs in supervised drug consumption facilities as

37 Baggio, Chong and Kwon, Helping Settle the Marijuana and Alcohol Debate: Evidence from Scanner Data, (2017). Available at SSRN: https://ssrn.com/abstract $=3063288$ (last accessed $3^{\text {rd }}$ of May 2018). 
opposed to the current regime of only allowing heroin injections. As for the question of whether use and possession for own use should be a criminal offense, the picture is not clear. The largest political parties, the Labour Party ('Arbeiderpartiet') and the Conservatives ('Høyre'), have both stated that they want to move the problem of drug use out of the criminal justice sector and into the health sector. Although the word decriminalisation has been mentioned on a few occasions by politicians in the Conservatives, both the Conservatives and the Labour Party have stated that the use of drugs must remain 'illegal'. To a large extent the word 'decriminalisation' is avoided, and often when politicians are asked directly about whether this actually amounts to a decriminalisation reform, they avoid the question by answering that they do not want to punish people with a drug addiction problem, but that drugs will still be illegal. There is no doubt that there is a gap between full decriminalisation and 'not punishing people with a drug addiction'. In the platform for the new minority government, it is stated that the police should have the right to impose treatment measures on drug users, and that failure to comply must be met with a sanction..$^{38}$ There is in other words no clearly stated goal of full decriminalisation.

Norwegian politicians often claim to look to the success of the Portuguese drug reform, which might lead to a Portuguese inspired model on sanctions. In the mandate for the Drug Reform Commission, it is even expressly specified that one of the tasks of the Commission is to evaluate whether the Portuguese reform can be an appropriate model for the Norwegian reform.

In Portugal, the use of drugs technically remains illegal, but the sanctions are administrative, not criminal. When someone is caught with a drug, they are brought before a 'Commission for the Dissuasion of Drug Abuse'. These commissions typically consist of a lawyer, a health professional and a social worker, and have a wide range of options available: Warnings, banning from certain places or meeting certain people, obligatory periodic visits to particular places, community services and ultimately even fines. The Commission may also revoke different sorts of licences. The Commission cannot mandate treatment, but the range of sanctions is thought to make it possible to motivate users with drug problems to seek treatment voluntarily.

Fines are relatively rare - in 2009 it was reported that only $4 \%$ of the reactions had been fines. As much as $68 \%$ of the reactions were provisional suspension of the process, as the user was not considered an addict. A further $15 \%$ were suspensions of the process with an agreement to undergo treatment. ${ }^{39}$

38 See https://www.regjeringen.no/no/dokumenter/politisk-plattform/id2585544/ (last accessed $3^{\text {rd }}$ of May 2018).

39 The overview on the Portuguese model is based on the EMCDDA Drug policy profiles - Portugal (2011): http://www.emcdda.europa.eu/system/files/publications/642/PolicyProfile_Portugal_ WEB_Final_289201.pdf (last accessed $3^{\text {rd }}$ of May 2018), and Woods 2011. 
Whether the Norwegian reform actually will end with something similar to the Portuguese regime is, however, far from certain. Most politicians do not seem to be fully aware of the details of the Portuguese regulation. The most common misconception is that there is room for criminal fines, which they also tend to believe are used significantly more than the Portuguese administrative fines actually are. As already pointed out, there is a striking reluctance to use the term decriminalisation. As many politicians fear that full decriminalisation will send 'wrong signals' to teenagers, they try to balance not having to punish people with drug addictions, with upholding a criminal sanction regime to be able to deter young people from doing drugs. As stated by the Deputy Leader of the Labour party, Hadia Tajik: There should still be criminal fines available to punish youngsters trying to 'show off' by using illegal drugs. ${ }^{40}$ Although this was contested by the Norwegian Secretary of Health, Deputy Leader of the Conservatives Bent Høie, ${ }^{41}$ we have seen MPs of the Conservatives stress, in connection with the above-mentioned remark in the Health Committee, that this is a reform first and foremost for those with a severe drug addiction.

One might also notice that the mandate for the Drug Reform Commission in its description of the Portuguese system highlights that the Portuguese Commission for the Dissuasion of Drug Abuse can impose 'sanctions' on those meeting before it. The new government platform does not even mention commissions, but simply gives the power to impose measures on those caught for drug use and minor possession to the police. In light of how the Norwegian police has practiced the current drug regulation over the last decade(s), there is not much reason to believe we will see anything resembling the lenient approach by the Portuguese commissions, suspending further action in nearly seven out of ten cases. It may also be pointed out that the Portuguese police seems less eager to search for drug users, as the commissions have around 6000 cases a year, in comparison to Norway where 12000 fines are handed out for use and possession of drugs with only half the population size of Portugal. ${ }^{42}$

We might fear that Norway ends up with a regime of mere 'forced' treatments that may be costly and simultaneously possibly increasing the burden of sanctions on the majority of users, on grounds of the politicians' fear of reclassifying drug use as a health issue may not be enough to deter the population from using drugs, and that even problematic users will not without further ado voluntarily subject themselves to treatment. This is quite contrary to the lessons from Portugal, where a lack of possibility for the commissions

40 In the Norwegian Newspapers Dagbladet ( $5^{\text {th }}$ of October 2016) and Aftenposten (11 ${ }^{\text {th }}$ of October 2016), https://www.aftenposten.no/meninger/debatt/i/n79qa/Rusmisbrukere-skal-fabehandling-Spenningssokere-kan-fa-bot--Hadia-Tajik (last accessed $3^{\text {rd }}$ of May 2018).

41 Dagbladet $16^{\text {th }}$ of October 2016, https:/www.dagbladet.no/kultur/hoie-hjelp-ikke-straffnarkotikabrukere/63942984 (last accessed $3^{\text {rd }}$ of May 2018).

$42 \quad$ See statistics above in chapter 2. 
to mandate treatment, did not prevent a significant rise in drug users seeking treatment within the decriminalisation regime. ${ }^{43}$ If the police, and not health workers, may end up with the authority to mandate treatment under threats of sanctions, it makes the situation even worse. One might seriously question what competence the police has to choose the right treatment for the different groups of drug users.

There are in practice two ways of implementing treatment as an alternative to criminal sanctions. One is actually enforcing the administered treatment, compulsory admission to rehabilitation. To most people, compulsory treatment, implemented by force if necessary, is a far worse intervention in their lives and physical integrity than the current criminal sanctions most users can expect. As the vast majority of drug users do not have an addiction problem, it seems hard to justify both medically-ethically and economically forcing all drug users into treatment programmes. Applying this kind of solution for drug use alone would fit badly with the current regime for compulsion treatment in Norwegian administrative law. ${ }^{44}$

It should be added that also the Penal Code contains certain forms of compulsory treatment. ${ }^{45}$ For instance, the Penal Code mentions certain 'alternative criminal reactions', which is not punishment, but still applied as reactions to offences. These alternative criminal reactions are listed in the Penal Code sect. 30 (see further sect. 62 ff.). Among the reactions listed here, is also transfer to compulsory mental health care. This reaction, however, targets criminally insane offenders and is limited to serious offences and risk for re-offending. Again, drug use can hardly to be said to conform to the seriousness of the acts that this reaction targets.

More likely would be the continuance and expansion of the current Norwegian regime of 'alternative' forms of punishment, i.e. alternatives to imprisonment and fines as the 'classical' forms of punishment. Today, there are several such alternative forms of punishment, including community service and youth punishment (Penal Code sect. $48 \mathrm{ff}$.). For drug crimes, the two main reactions today are the drug urine test contracts mostly offered to young people ('ruskontrakt'), and the court supervised drug rehabilitation program ('narkotikaprogram med domstolskontroll'). The latter is explicitly regulated in the Penal Code sect. $37 \mathrm{f}$ ) as one particular criterion that can be set for a conditional prison sentence. The drug urine test contracts rest on a more creative, although perfect-

$43 \quad$ Woods 2011 p. 34.

44 For a comprehensive overview on the Norwegian administrative law on compulsory treatment see Søvig, Tvang overfor rusmiddelavhengige - Sosialtjenesteloven \$\$ 6-2 til 6-3 (Fagbokforlaget, 2007) and Østenstad, Heimelsspørsmål $i$ behandling og omsorg overfor psykisk utviklingshemma og aldersdemente. Rettslege og etiske problemstillingar ved bruk av tvang og inngrep utan gyldig samtykke (Fagbokforlaget 2011).

45 For a description of the Norwegian regulation of criminal sanctions, see Gröning, Husabø and Jacobsen, Frihet, forbrytelse og straff - En systematisk fremstilling av norsk strafferett (Fagbokforlaget 2016) part IV. 
ly solid legal basis. According to the Criminal Procedure Act sect. 69, the police may waive prosecution, even if a criminal act is considered proven. According to sect. 69 third paragraph, this waiver of prosecution may be conditional, with reference to the possible conditions listed in the Penal Code sect. 37. The Penal Code sect. $37 \mathrm{k}$ gives a fairly wide discretion to set conditions found appropriate, which is the basis for the urine drug test contracts. The drug urine test contracts and the court supervised drug rehabilitation program both rely on underlying criminal sanctions - only if the subject completes the program, the 'classical' criminal sanctions are dropped.

Some politicians promote these alternative forms of punishment as a more human alternative to traditional criminal sanctions, while ignoring their invasive character and the underlying threat of ordinary criminal sanctions for those unable to complete the programs. The court supervised drug rehabilitation program is a good alternative to prison for those with drug problems who are motivated for treatment. For ordinary use and possession, this is not currently practiced as a sanction. It is administered for more severe criminal offenses, typically crimes committed in order to finance drug use. It might be questioned how many would actually subject themselves to such an invasive program if the alternative is simply fines. It is hard to see that the court supervised drug rehabilitation program can offer a realistic alternative to the current regime. It also poses an important moral dilemma: Treatment facilities have a limited number of places. If we are to treat people who do not really need treatment, or are not particularly motivated, they will occupy places which are coveted by others. It means that people with drug problems who are motivated for treatment will have to wait, while treatment instead is given to people with less need for it, and less chance of success. It is highly problematic to prioritise treatment places on other criteria than medical ones.

The drug urine test contracts have similar problems. They are also invasive, but as young people are more subject to pressure from family and police, the tendency is that many accept these contracts. The main problem is, as with the above-mentioned court supervised rehabilitation program, a significant failure rate, and for the most vulnerable users, those who typically fail, failing the program will lead to classic 'hard' criminal reactions. For example, one might easily imagine four young boys being caught smoking cannabis. Three of them have resourceful parents, quickly identifying the fourth kid as the problem. These three might never have developed a drug problem, and complete the urine test contract regime. The fourth kid, who is abused at home, is isolated from his friends, fails his urine contract and develops a more severe drug problem. The last kid is the most vulnerable, and the one in most need of the society's assistance. With the current regime, he is the one that will be subject to criminal sanctions on top of all his other problems. Another particularly dangerous side effect of these urine contracts is that they 
might lead young people to stronger synthetic drugs that are not as easily tracked in urine as cannabis. ${ }^{46}$

The new Committee on a Norwegian drug reform has an important task of enlightening the politicians on the details of the Portuguese reform. They need to show that alternative criminal sanctions have already been in use for quite some time without changing the current sad state of the Norwegian drug scene, why the complete removal of criminal sanctions should be a central element of the reform, and finally how this can be done in Norwegian law. Hopes are that Norway will properly scrutinise the Portuguese model, come up with a balanced plan for treating drug use as a possible health problem and not make people's lives more difficult by administering unnecessary and imposing sanctions. A complete decriminalisation of use and possession of small amounts of drugs should be a cornerstone in such a reform.

46 The evaluation of the drug urine test contracts for young people also concluded that these regimes were far more successful when experienced as actual help and not as punishment and control by the person subjected to it, see Flinkiser og 'dropouts'. Erfaringer med ungdom på frivillig ruskontrakt. KoRus 2015: https://www.korusoslo.no/wp-content/uploads/Web_Korus_ Frivillig-ruskontrakt-1.pdf (last accessed $3^{\text {rd }}$ of May 2018). 